\title{
ANALISIS PERUBAHAN GARIS PANTAI DENGAN MENGGUNAKAN CITRA PENGINDERAAN JAUH \\ (STUDI KASUS DI KECAMATAN TALAWI KABUPATEN BATUBARA)
}

\author{
Darwin P Lubis ${ }^{1}$, Mbina Pinem ${ }^{1}$, M.Ali N Simanjuntak ${ }^{1}$ \\ 1Jurusan Pendidikan Geografi Fakultas Ilmu Sosial Universitas Negeri Medan \\ Jl. Willem Iskandar Psr V Medan Estate Medan, 20211 Indonesia \\ Email : darwinparlaunganlubis@gmail.com
}

\begin{abstract}
Abstrak
Penelitian ini bertujuan untuk mengetahui (1) Laju perubahan garis pantai dengan menggunakan citra pengindraan jauh dikawasan pesisir pantai Kecamatan Talawi. (2) Tingkat akurasi dalam menganalisis perubahan garis pantai dikawasan pesisir pantai Kecamatan Talawi.

Penelitian ini akan dilaksanakan di Kabupaten Batu Bara Kecamatan Talawi tepatnya di pesisir pantai Kecamatan Talawi. Lokasi ini dipilih atas pertimbangan sebagai berikut : (1) Terdapatnya perubahan pola garis pantai di kawasan pesisir pantai Kecamatan Talawi. (2) Mengkaji secara mendalam mengenai pola perubahan garis pantai di kawasan pesisir Kecamatan Talawi.

Hasil penelitian ini menunjukkan bahwa aada rentang waktu tahun 2008 - 2011 terjadi penambahan luas wilayah pesisir (Akresi) sebesar ,770 Km² dengan laju penambahan 1,192 $\mathrm{Km}^{2}$ per-tahunnya. Sedangkan pada rentang waktu 2011 - 2014 besarnya akresi hanya 0,087 $\mathrm{Km}^{2}$ dengan laju penambahan sebesar 0,021 $\mathrm{Km}^{2}$ atau $21 \mathrm{~m}^{2}$ per-tahunnya. Pengurangan garis pantai (abrasi) pada tahun 2011 - 2014 yakni sebesar 0,704 Km² dengan laju abrasi 0,176 Km² atau $176 \mathrm{~m}^{2}$ per-tahunnya. Perhitungan tingkat akurasi interpretasi Perubahan Garis pantai citra Landsat tahun 2008 - tahun 2014 diperoleh akurasi seluruh pemetaan sebesar $90,9 \%$.
\end{abstract}

Kata Kunci: Pantai, Penginderaan Jauh, Kabupaten Batu Bara

\section{PENDAHULUAN}

Indonesia merupakan negara yang memiliki kawasan pesisir sangat luas, karena Indonesia merupakan Negara kepulauan dengangaris pantai mencapai sepanjang $81.000 \mathrm{~km}$. Selain menempati wilayah yang sangat luas, kawasan pesisir yang terdiri dari berbagai ekosistem pendukung seperti ekosistem hutan mangrove, terumbu karang, padang lamun dan lahan basah tersebut memiliki keanekaragaman hayati dan berbagai sumber daya alam seperti ikan, dan bahan-bahan tambang yang bernilai tinggi. Kemudahan akses terhadap kawasan pesisir cenderung meningkatkan laju pemanfaatan wilayah pesisir di tahun-tahun mendatang, baik dalam hal pemanfaatan sumberdaya ekonomi maupun pemanfaatan ruang.Selain itu, hal lain yang tidak boleh diabaikan adalah fakta yang menunjukkan bahwa tidak kurang dari $60 \%$ penduduk Indonesia bermukim di kawasan pesisir (DKP, 2002)

Secara ekonomis pantai dapat memberikan pendapatan kepada Negara dan penduduk karena pantai sangat berpotensi sebagai daerah penghasil ikan, wisata, kegiatan industri, pemukirnan, pelabuhan, pertambangan, konservasi lahan dan lain-lain. Tetapi dengan adanya proses dan tenaga yang bersifat alami atau non alami maka pantai akan mengalami perubahan, salah satunya adalah adanya perubahan garis pantai. Wilayah pesisir cenderung mengalami tekanan 
penggunaan yang berlebihan oleh aktifitas kehidupan manusia, terutama permukiman, industri dan berbagai kegiatan ekstraktif lainnya. Baik secara langsung maupun tidak langsung berbagai bentuk aktifitas tersebut dapat mengubah keseimbangan proses alami diwilayah pesisir sehingga menimbulkan dampak terjadinya kerusakan.

Garis pantai merupakan batas dari ekosistem laut dan ekosistem darat yang dalam pengolahannya kedua ekosistem ini memiliki karakteristik yang berbeda. Garis pantai juga berguna dalam penentuan batas wilayah Negara atau pun daerah untuk pengolahan sumberdaya alam yang ada contohnya ZEE diukur sejauh 200 mil dari garis pantai kearah laut lepas, kemudian UU No. 22 Tahun 1999, Pasal 3 menyatakan bahwa " Wilayah Daerah Propinsi terdiri atas wilayah darat dan wilayah laut sejauh duabelas mil laut yang diukur dari garis pantai kearah laut lepas dan/atau kearah perairan kepulauan".

Pemanfaatan lahan di Pantai Timur Sumatera Utara sebagian besar untuk pemukiman, tambak, obyek wisata dan lain - lain. Akibat dari pemanfaatan lahan tersebut pantai mengalami perubahan, hal ini juga disebabkan oleh pemanfaatan lahan disekitar DAS. Perubahan pantai di Pantai Timur Sumatera Utara juga oleh proses deposisi yang rnengakibatkan perkembangan pantai di daerah muara sungai maupun sepanjang pantai. Material yang mengendap biasanya berasal dari aliran sungai serta material dari laut yang terbawa oleh arus dan gelombang.

Kawasan pantai bersifat dinamis, artinya ruang pantai (bentuk dan lokasi) berubah dengan cepat sebagai reaksi terhadap proses alam dan aktivitas manusia (Solihuddin, 2010). Aktivitas manusia dalam memanfaatkan sumber kekayaan di kawasan pantai sering tumpang tindih, sehingga tidak jarang kesehatan ekosistem pantai menjadi turun, pantai yang menjadi daerah pertemuan antara laut dan daratan menjadi terancam fungsinya sebagai habitat maupun sebagai benteng perlindungan infrastruktur yang ada di darat.

Demikian juga halnya dengan Kabupaten Batu Bara, menurut data terakhir dari hasil pemotretan udara (citra satelite) tahun 2001, menunjukan bahwa hutan mangrove yang ada di Kabupaten Batu Bara adalah seluas 1.598,38 ha. Jika dibandingkan dengan keadaan pada tahun 2010, dimana luas hutan mangrove yang ada tersisa hanya 876,06 ha. Pengurangan luas hutan mangrove salah satunya disebabkan tingginya laju abrasi, terlihat di sepanjang pesisir pantai Kecamatan Talawi yang luas hutan mangrovenya berkurang dan abrasi air laut mencapai pemukiman penduduk. (Dinas Kehutanan Batu Bara, 2010).Untuk keperluan perencanaan pengelolaan kawasan pantai, diperlukan penelitian tentang perubahan garis pantai sehingga pembangunan yang dilakukan tidak berdampak terhadap lingkungan (Sakkaet al., 2011).

Perubahan terhadap garis pantai adalah satu proses tanpa henti (terus menerus) melalui berbagai proses baik pengikisan (abrasi) maupun penambahan (akresi) pantai yang diakibatkan oleh pergerakan sedimen, tindakan ombak dan penggunaan tanah. Gelombang yang terjadi akibat pergeseran lempeng dasar laut atau tsunami menyapu daratan, sehingga dapat merubah daratan pantai dan penutupan lahan yang ada di pesisir daratan tersebut. Perubahan daratan pantai itu sendiri yaitu akibat tumpukan sedimen yang terbawa oleh gelombang maupun sedimen pantai yang terkikis dan terbawa oleh gelombang atau arus laut. Kajian perubahan garis pantai sendiri penting dilakukan sebagai acuan dalam pembangunan wilayah pesisir dan pelabuhan, pariwisata serta kegiatan penangkapan dan budidaya perikanan.

Berdasarkan kondisi yang terjadi pada kawasan pesisir pantai Kecamatan 
Talawi, maka diperlukan kajian atau penelitian terhadap perubahan garis pantai di kawasan pesisir pantai Kecamatan Talawi untuk memberikan informasi secara spasial dan akurat. Saat ini metode teknologi penginderaan jauh dapat mengamati fenomena perubahan garis pantai untuk setiap tahunnya. Keunggulan metode ini dibandingkan metode yang lainnya yaitu mengambarkan obyek daerah dan gejala permukaan bumi dengan wujud dan letak obyek yang mirip dengan wujud dan letak obyek di bumi. Relatip lengkap meliputi daerah yang luas dan permanen dapat diwujudkan dalam tiga dimensi sehingga memperjelas kondisi relief dan dapat dibuat cepat meskipun daerahnya sulit dijangkau dan datanya bersifat up to date.

Keindahan beberapa pantai yang selama ini sudah dibuka untuk wisata umum mulai terganggu akibat abrasi air laut. Seperti yang terjadi pada salah satu pantai di kecamatan talawi yakni pantai bunga, mesjid lama. Sepanjang pantai yang mencapai sekitar $1500 \mathrm{~m}$, Sebelumnya ada penanaman bakau sepanjang pantai tapi sekarang nyaris tak bersisa dihantam abrasi laut. Tidak sebatas merusak pohon bakau dan api-api yang banyak tumbuh di sana, abrasi juga dikuatirkan akan mencapai pemukiman penduduk. Kerugian lebih besar dan kesulitan penanggulangan bencana akan memakan lebih banyak waktu dan materi. Persoalan tepi pantai bunga laut indah ternyata tidak sebatas gangguan ekosistem. Ancaman lebih besar datang dari pihak-pihak yang mengklaim tepi pantai itu sudah dikuasai perusahaan swasta. Terlebih, keterlibatan dalam mengurus pantai untuk tempat wisata umum dianggap sebagai pengganggu di sana (Harian SIB Batubara, Agustus 2014).

Dengan melihat wacana diatas maka dilakukan pengamatan perubahan garis pantai dipantai Sumatera Utara, tepatnya dikawasan pesisir pantai Kecamatan Talawi menggunakan
Available at http://jurnal.unimed.ac.id/2012/index.php/geo e-ISSN: 2549-7057 | p-ISSN: 2085-8167

teknologi penginderaan jauh dengan data citra landsat dari tahun 2008 - 2014. Penggunaan data satelit merupakan cara yang efektif untuk pemetaan penutup lahan dan vegetasi, karena data satelit memiliki rentang waktu yang dapat diatur untuk pengambilan data citra untuk lokasi yang sama. Perkembangan teknologi penginderaan jauh saat ini,mengarah pada peningkatan resolusi spasial dan temporal untuk perolehan informasi dan keperluan monitoring.

Mengingat sangat terkaitnya permasalahan perubahan lahan ini dengan aspek keruangan, pendekatan menggunakan Sistem Informasi Geografis (SIG) juga diperlukan untuk menambah informasi yang akan didapat, seperti sistem input data peta yangbaik. Pendekatan ini berdasarkan peubahpeubah terukur dan kesisteman yaitu dengan menerapkan teknologi berbasis geospasial. SIG memiliki kemampuan untuk mempresentasikan unsur-unsur yang terdapat dipermukaan bumi dengan cara mengumpulkan, menyimpan, memanipulasi, menganalisa dan menampilkan kembali kondisi-kondisi alam (bereferensi geografis).

Penerapan SIG dapat mengintegrasikan berbagai karakterisik lingkungan wilayah pesisir baik secara spasial maupun deskriptif. Dengan memperhatikan hal tersebut maka diperlukan data-data spasial kawasan pesisir yang berguna dalam pemanfaatan dan pengelolaaan sumberdaya dan ruang di kawasan pesisir yang direncanakan secara berkelanjutan. Maka perlu diadakan penelitian tentang "Analisa Perubahan Garis Pantai dengan Menggunakan Citra Penginderaan Jauh di kawasan Pesisir Pantai Kecamatan Talawi Kabupaten Batubara"

Tujuan yang akan dicapai dalam penelitian ini adalah:

1. Mengetahui Laju perubahan garis pantai dengan menggunakan citra pengindraan jauh dikawasan pesisir pantai Kecamatan Talaw 
2. Bagaimana tingkat akurasi dalam menganalisis perubahan garis pantai dikawasan pesisir pantai Kecamatan Talawi.

\section{METODE PENELITIAN}

Penelitian ini akan dilaksanakan di Kabupaten Batu Bara Kecamatan Talawi tepatnya di pesisir pantai Kecamatan Talawi. Lokasi ini dipilih atas pertimbangan sebagai berikut : (1) Terdapatnya perubahan pola garis pantai di kawasan pesisir pantai Kecamatan Talawi. (2) Mengkaji secara mendalam mengenai pola perubahan garis pantai di kawasan pesisir Kecamatan Talawi.

Teknik analisis data yang di gunakan dalam penelitian ini adalah dengan analisis deskriptif kuantitatif. Pengolahan datanya meliputi:

\section{Pengorganisasian Data}

Data yang akan di gunakan di pilih dari tahun 2008 sampai tahun 2014 yang terbebas dari awan dan dipilih satu citra yang mewakili satu tahun. Citra landsat akan di olah dan di susun data vektor-nya berdasarkan urutan tahunnya untuk mendapatkan panjang akresi dan abrasi.

2. Perhitungan Perubahan Garis Pantai

Perhitungan perubahan garis Pantai menggunakan formula dari Thieler et.al (2008) dengan jarak vektor garis pantai ditiap tahunnya di hitung. Sehingga pergerakan total garis pantai dapat di ketahui. Pengukuran ini menggunakan program Digital Shoreline Analysis System (DSAS).

3. Penghitungan tingkat akurasi

Penghitungan tingkat akurasi dilakukan setelah analisis dan diinterpretasi untuk mengetahui keakuratan dari proses analisis dan hasil interpretasi yang dilakukan. Perhitungan dilakukan dengan menentukan sampel - sampel berupa objek pada citra terbaru yang terdekat dengan tahun proses pengolahan citra. Sampel ini akan dicatat koordinatnya dan dibandingkan dengan keadaan nyata untuk melihat sesuai atau tidaknya dengan yang sebenarnya.

Prosedur yang dilakukan dalam penelitian ini adalah sebagai berikut

\section{Tahap Memperoleh Citra}

Tahapan awal yang dilakukan dalam mengadakan citra adalah dengan men-download data citra landsat dari situs resmi USGS (U.S Geological Survey).

2. Proses Pra - Interpretasi

Setelah selesai tahap pertama yaitu pengadaan citra maka langkah selanjutnya adalah proses pengolahan citra sebelum bisa di olah. Proses ini memerlukan Aplikasi bernama ENVI dan saya memakai versi 4.7. Pada tahap ini selain perlu mempersiapkan software, perlu juga di persiapkan vector file dari daerah penelitian untuk membuat ROI (region of Interest) yang akan diperlukan dalam memotong citra yang kita inginkan menjadi wilayah penelitian saja sehingga memudahkan nantinya dalam mengolah data citra tersebut

3. Proses Mendigitasi/Interprerasi Citra

Setelah selesai menyiapkan citra yang telah di lakukan sebelumnya, dilanjutkan dengan mendigitasi /interpretasi citra agas bisa di olah nantinya.proses digitasi akan menghasilkan peta gars pantai dalam bentuk Shapefile yang natinya akan di proses lebih lanjut pada ArcGIS 10.1 sehingga dapat diketahui perubahan garis pantainya

4. Tahap Meng-Overlay Garis Pantai tahun 2008, 2011, dan 2014

Pertama-tama adalah membuka program ArcGIS 10.1 dan akan dihadapkan pada tampilan toolbar ArcGIS, kemudian memanggil file shp yang telah didigitasi sebelumnya yaitu Shapefile "Pantai Talawi",

5. Output (Layout Peta)

Proses akhir dari interpretasi citra adalah membuat hasil akhir (output) 
yang berupa peta perubahan penggunaan lahan, baik itu dalam bentuk softcopy atau hardcopy (printout). Adapun langkah dalam membuat layout adalah dengan memilih View > Layout view.

Kemudian atur dan sesuaikan bentuk peta dengan atribut yang diinginkan sesuai dengan kaidah pembuatan peta yang benar. Setelah semua selesai simpan data yang telah selesai di-layout dengan cara pilih file $>$ export map > Jpeg > ok

\section{HASIL DAN PEMBAHASAN Analisis hasil interpretasi citra LANDSAT}

Hasil interpretasi citra Landsat tahun tahun 2008, tahun 2011, dan tahun 2014 yang telah di digitasi, menunjukan perubahan pada daerah garis pantai yang terdapat di Kawasan Pesisir Kecamatan Talawi Kabupaten Batubara pada tahun 2008 - tahun 2011 terdapat perubahan signifikan dalam hal penambahan daratan (akresi), sedangkan pada tahun 2008 - 2014 juga terjadi penambahan daratan (akresi) kecuali pada 5 (lima) titik yang terlihat pada kurva yang terdapat perubahan yg nampak dari daerah penelitian ini, yakni 3 (tiga) titik pada wilayah desa Dahari Selebar, dan 2 (dua) titik pada wilayah desa Mesjid Lama seperti yg di tunjukan pada Gambar 1.

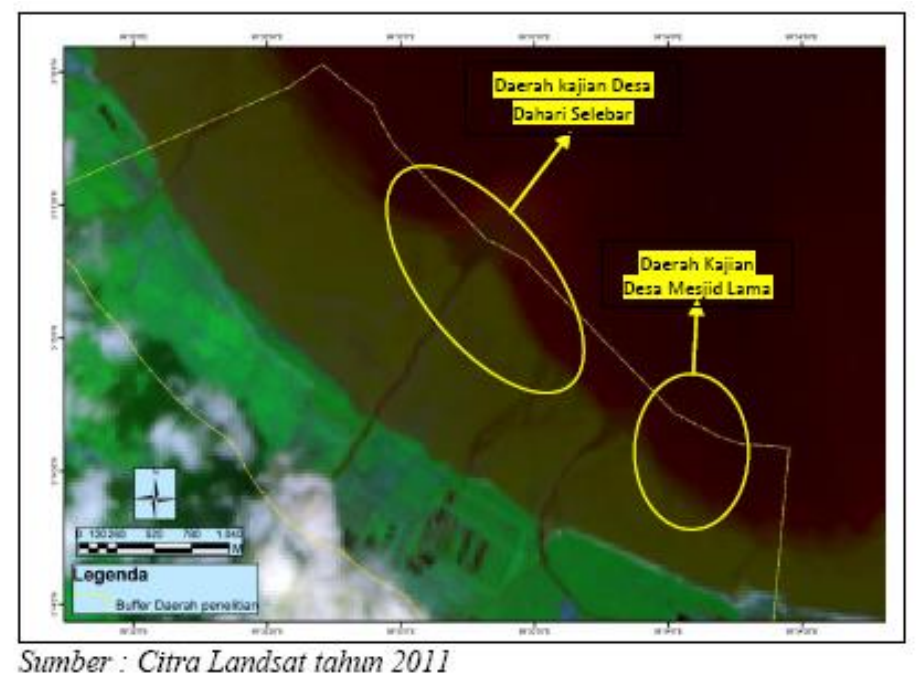

Gambar 1. Daerah terjadinya pengurangan daratan (Abrasi)

Pengelolaan awal citra merupakan tahap awal dari pengelolaan citra satelit Landsat untuk meningkatkan kualitas data citra dengan lokasi kawasan pesisit kecamatan talawi kabupaten batubara. Untuk itu koreksi distorsi atau kesalahan data perlu di lakukan sebelum data lebih lanjut. Distorsi atau kesalahan geometrik ini tidak nampak secara nyata dalam citra, namun kesalahan akibat posisi geometrik ini dapat berakibat fatal karena dapat menyebabkan terjadinya kesulitan dalam melakukan pengecekan lapangan terhadap objek yang tampak pada citra, distorsi ukuran luas, kesulitan dalam proses intehrasi citra dengan sumber yang lain, dan tidak memungkinkan dilakukannya perbandingan piksel demi piksel.

Di daerah penelitian terdapat 3 (tiga) scene citra satelit Landsat, sehingga untuk menampilkan visualisasi daerah penelitian perlu di lakukan pem-fokusan daerah penelitian dengan cara mem-buffer sekitar daerah penelitian dengan kisaran sekitar $\pm 1 \mathrm{~km}$. Pem-bufferan dan pemotongan citra selain untuk lebih memfokuskan daerah penelitian yg di amati juga dapat mengurasi kapasitas data agar pengolahan data dapat lebih cepat dan lebih ringan. Pada proses ini terlebih dahulu dilakukan penentuan 
derah penelitian, kemudia menarik garis yg akan di buffer sepanjang $\pm 6 \mathrm{Km}$, dan jarak dari garis ke arah tepian buffer \pm 1 $\mathrm{Km}$. Pem-bufferan dan pemotongan daerah yag sepetri terihat pada gambar 2 . menunjukkan daerah yg semulanya cukup besar menjadi lebih jelas terlihat.

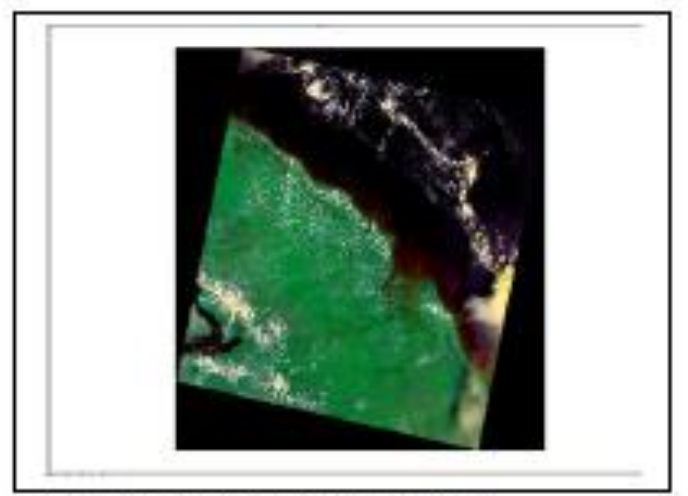

Sumber : Citra Landsat 2008

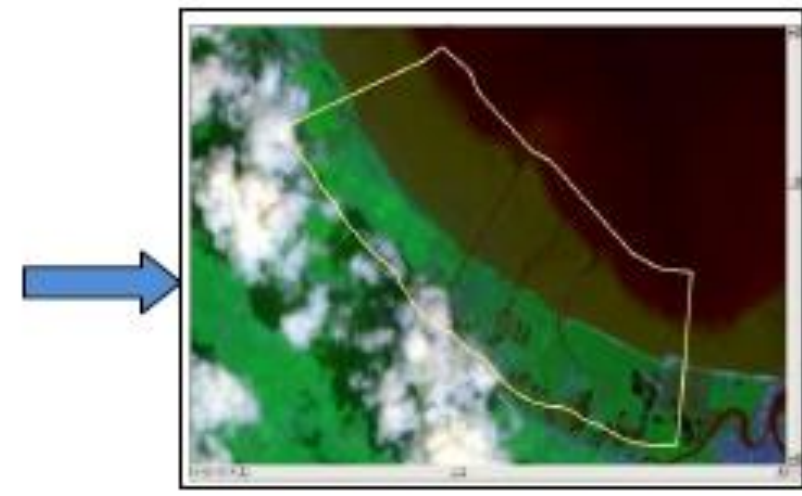

Gambar 2. Pemotongan citra sesuai dengan daerah penelitian

Perubahan Garis pantai di Kawasan Pesisir Kecamatan Talawi pada Tahun 2008, Tahun 2011, dan Tahun 2014.

Hasil interpretasi yang dilakukan terhadap citra landsat di kawasan pesisir pantai Kecamatan Talawi dan kemudian masing-masing hasil interpretasi tersebut di tumpang-tindikan (Overlay) sehingga menghasilkan beberapa garis pantai yang saling - silang. Hasil ini kemudian di pilah, kemudian dikelompokan menjadi perubahan bersifat Abrasi atau perubahan bersifat Akresi. Setelah dilakukan Identifikasi lokasi terjadinya abrasi dan akresi pantai dengan cara menumpang susunkan (overlay) garis pantai tahun terlama dengan garis pantai tahun terkini.

Analisis laju abrasi dan akresi dilakukan dengan memanfaatkan perangkat lunak (software) DSAS atau
Digital Shoreline Analysis System. Analisis dilakukan terhadap perubahan garis pantai untuk 3 tahun data perekaman yang di peroleh dari pengolahan Citra Landsat thn. 2008, 2011, dan 2014. Sebagai referensi terhadap perubahan garis pantai untuk masing - masing tahun tersebut, dibuat garis dasar (baseline) yang sejajar dengan garis pantai. Selanjutnya dibuat garis transek (transect) yang tegak lurus dengan garis dasar untuk membagi bagian - bagian garis pantai dengan interval 30 meter. Interval 30 meter di ambil dengan pertimbangan resolusi dari citra landsat sendiri merupakan 30 meter seperti yang di perlihatkan pada Gambar 3. Kemudia laju perubahan garis pantai akan di analisis dengan pendekatan Linear Regression Rates (LRR).

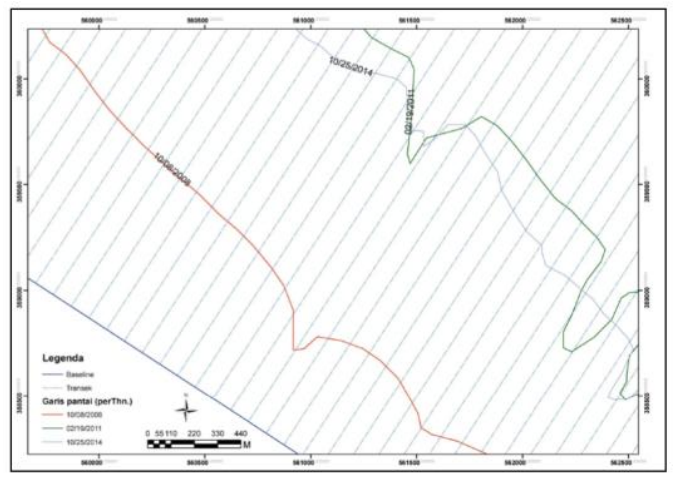

Gambar 3. Garis Pantai Hasil Interpretasi 


\section{gèrafi}

Analisis Laju Abrasi dan Akresi Tahun 2008 - 2011

Gambar 4 menunjukkan sebagian besar pantai Kecamatan Talawi mengalami perubahan yang menunjukan tingkat akresi yang signifikan pada tahun 2008 - tahun 2011. Perubahan ini
Available at http://jurnal.unimed.ac.id/2012/index.php/geo e-ISSN: 2549-7057 | p-ISSN: 2085-8167

ditunjukan dengan keseluruhan wilayah terjadi penambahan daratan, sedangkan pada tahun 2011 - 2014 perubahan bersifat lebih bervariasi antara besarnya akresi dan abrasi.

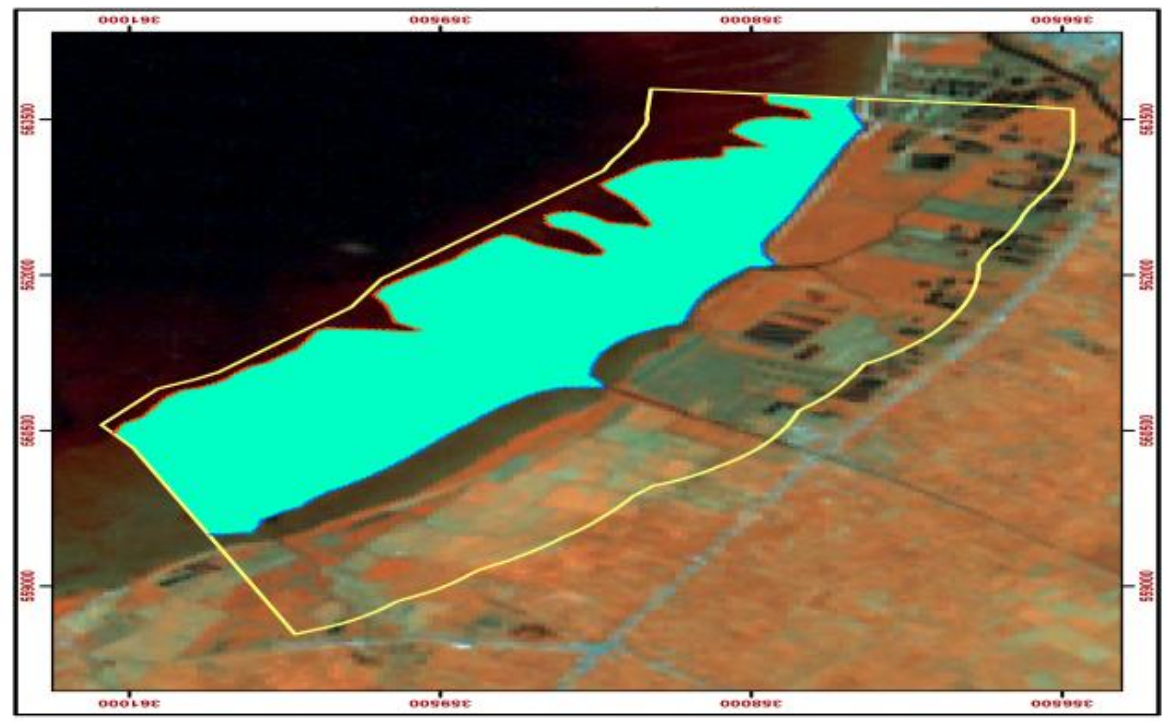

Gambar 4. Pantai Kecamatan Talawi yang mengalami akresi Tahun 2008 - 2011

Berdasarkan hasil dari interpretasi, luas wilayah yang bertambah pada tahun 2008 - 2011 mencapai $4,77 \mathrm{~km}^{2}$ .Penambahan tersebut tersebar di 2 (dua) desa yang berbatasan langsung dengan laut, yakni Desa Dahari Selebar dengan luas 3,07 $\mathrm{Km}^{2}$ dan desa Mesjid Lama dengan luas $1,69 \mathrm{Km}^{2}$. dengan rata - rata akresi sebesar 1,192 $\mathrm{Km}^{2}$ per tahunnya, dengan penambahan tepi pantai terjauh sejauh $1,3 \mathrm{Km}$ di desa dahari selebar dan terdedekat sejauh 272 meter yang terletak di desa mesjid lama.

Tabel 1. Perubahan garis pantai Kecamatan Talawi Thn. 2008 - 2011

\begin{tabular}{|c|c|c|c|}
\hline No & \multirow{2}{*}{ Nama Desa } & \multicolumn{2}{|c|}{ Luas $\left(\mathrm{Km}^{2}\right)$} \\
\cline { 3 - 4 } & & Abrasi & Akresi \\
\hline 1 & Dahari Selebar & - & 3,071 \\
2 & Mesjid Lama & - & 1,699 \\
\hline \multicolumn{2}{|c|}{ Jumlah } & - & 4,770 \\
\hline
\end{tabular}

Sumber : Data Olahan, 2018 - 2011

Analisis Laju Abrasi dan Akresi Tahun 2011 - 2014

Pada rentang waktu tahun 2011 2014, perubaha lebih bersifat variatif. Hal ini seperti yang ditunjukan dari hasil overlay yang di lakukan terhadap hasil interpretasi dan digitasi citra landsat pada rentang waktu tahun 2011 - 2014. 


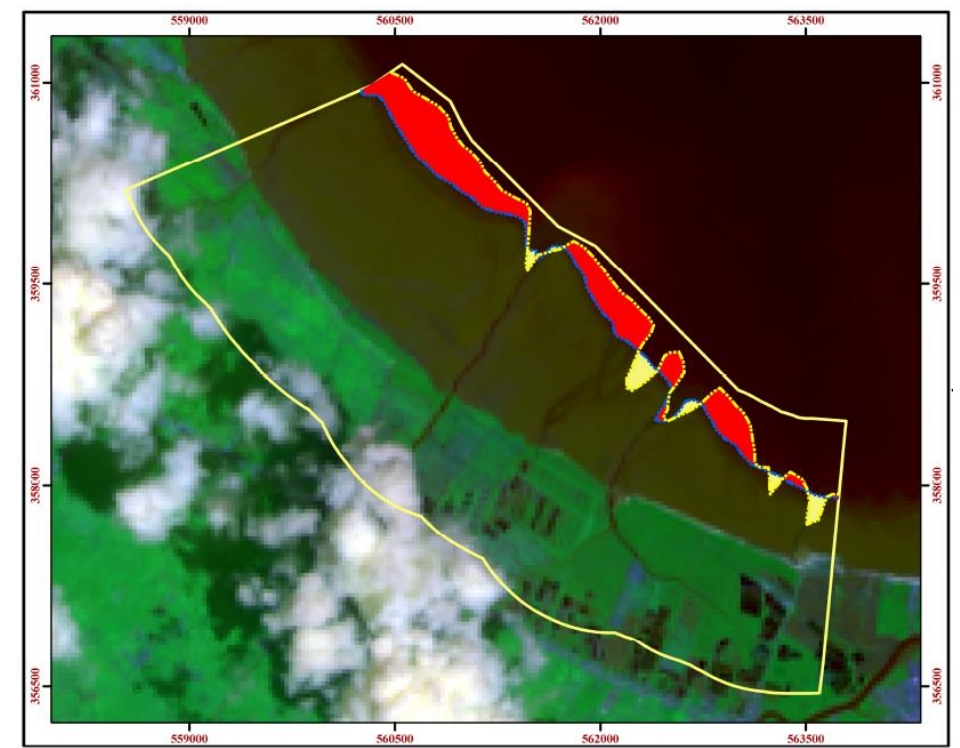

Gambar 5. Pantai Kecamatan Talawi yang mengalami akresi Tahun 2011 - 2014

Tabel 2. Perubahan Garis Pantai Kecamatan Talawi Tahun 2011 - 2014

\begin{tabular}{|c|c|c|c|}
\hline No & \multirow{2}{*}{ Nama Desa } & \multicolumn{2}{|c|}{ Luas $\left(\mathrm{Km}^{2}\right)$} \\
\cline { 3 - 4 } & & Abrasi & Akresi \\
\hline 1 & Dahari Selebar & 0,468 & 0,012 \\
2 & Mesjid Lama & 0,237 & 0,075 \\
\hline \multicolumn{2}{|c|}{ Jumlah } & 0,704 & 0,087 \\
\hline
\end{tabular}

Sumber : Data Olahan, 2011 - 2014

Dari tabel di atas terlihat, bahwa pada rentang tahun 2011 - 2014 penambahan daratan tidak sesignifikan pada rentang tahun 2008 - 2011. Pada rentang tahun 2011 - 2014 penambahan daratan (akresi) berjumlah 0,087 $\mathrm{Km}^{2}$, dengan luas masing - masing yakni: Desa Dahari Selebar seluas 0, $012 \mathrm{Km}^{2}$, dan Desa Mesjid Lama seluas 0, $075 \mathrm{Km}^{2}$. Sedangkan pada rentang tahun 2011 2014 pengurangan daratan (abrasi) berjumlah 0,704 $\mathrm{Km}^{2}$, dengan luas masing - masing yakni; Desa Dahari Selebar seluas 0,468 $\mathrm{Km}^{2}$, dan Desa Mesjid Lama seluas $0,237 \mathrm{Km}^{2}$, dengan penambahan tepi pantai terjauh sepanjang 243 meter dan terdekat sejauh 34 meter dan untuk pengurangan tepi pantai terjauh sejauh 357 meter dan terendah sejauh 25 meter.

\section{Tingkat Akurasi Interpretasi Citra LandSat}

Citra Landsat merupakan citra yang cocok di gunakan dalam penelitian yang bersifat temporal. Satelit Landsat akan memotret tempat yang sama dalam 16 hari sekali.sehingga memudahkan kita untuk memilih waktu yang sesuai dengan penelitian kita. Satelit Landsat juga memiliki band lengkap, sehingga memudahkan kita juga dalam meng kompositkan sesuai dengan kebutuhan kita. Satelit Landsat menggunakan sensor ETM+ (Enhanced Thematic Mapper Plus) yang merupakan sebuah scanner. Lebarnya pemotretan seluas $185 \mathrm{Km}$ dengan arah dari utara keselatan. Kelebihan dari Landsat lainnya ialah menggunakan band pankromatik dengan resolusi 15 meter dan band thermal (band 6) yang mempunya resolusi 60 meter.

Kawasan Pesisir Pantai Kecamatan Talawi merupakan daerah yang memiliki batas laut, dimana yang termasuk langsung berbatasan dengan laut di 
kawasan pesisir pantai kecamatan talawi adalah desa Dahari Selebar dan Desa Mesjid Lama. Untuk melihat apakan peta perubahan garis pantai yang telah di digitasi sesuai dengan hasil dilapangan atau tidaknya, diperlukan uji keakuratan.

Uji keakuratan ini dilakukan dengan cara mengambil sampel di peta yang didigitasi dari citra kemudian mencocokan data di lapangan. Di karenakan waktu penelitian tidak sama
Available at http://jurnal.unimed.ac.id/2012/index.php/geo e-ISSN: 2549-7057 | p-ISSN: 2085-8167

dengan waktu terjadinya perekaman citra, maka peneliti mengambil beberapa titik yang mana memiliki waktu terdekat dengan pengamatan, dan diharapkan dapat mewakili dari hasil keseluruhan.titik yang di ambil sebanyak $50 \%$ dari masing - masing perubahan dengan rentang waktu terdekat yakni tahun 2014. Titik di ambil secara acak dengan jumlah 11 titik (Lihat Gambar 6.)

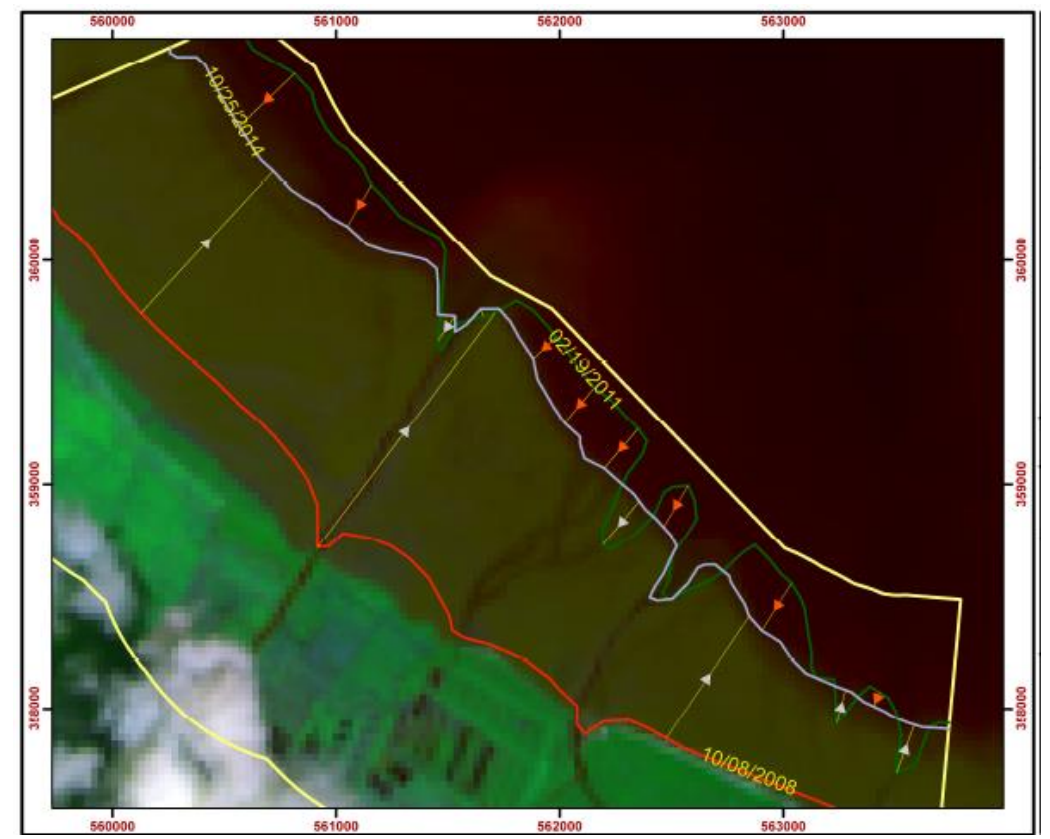

Gambar 6. Arah Laju Perubahan Garis Pantai

Berdasarkan hasil pengecekan titik sampel yang di lakukan di lapangan sebanyak 25 titik. Titik sampel yang sesuai dengan hasil interpretasi dan mengalami perubahan yang tampak sebanyak 10 titik sehingga diperoleh nilai akurasinya ebesar 90,9\% sedangkan yang tidak tampak dengan jelas perubahannya sebanyak 1 titik samperl. Pengecekan dilakukan dengan bantuan Global Positioning System (GPS). Alat ini dapat menentukan keberadaan lokasi contoh tersebut melalui ketepatan koordinat lokasi yang di Ground Check. Menurut Short (1982) dan Estes dalam Harianto (2011), nilai akurasi yang mempunyai tingkat ketelitian $\geq 80 \%$ sudah dianggap akurat. Rumus untuk menentukan nilai akurasi adalah :

Jumlah titik yang benar di lapangan x 100\% Jumlah seluruh titik yang diambil

Penetapan akurasi dari klasifikasi citra sangat penting untuk mengevaluasi kualitas peta yang dikembangkan dari data penginderaan jauh. Keakuratan klasifikasi diperoleh dari perbandingan antara jumlah piksel yang dikelaskan secara benar pada setiap kelas dengan jumlah contoh yang digunakan. Evaluasi ini menguji tingkat keakuratan secara visual dari hasil klasifikasi terbimbing dengan menggunakan titik-titik kontrol lapangan untuk uji akurasi. Titik-titik lain yang ditentukan sebanyak kelas-kelas 
yang telah ditetapkan dalam klasifikasi pada lokasi diluar area contoh yang telah digunakan sebelumnya. Evaluasi akurasi terhadap besarnya kesalahan klasifikasi area contoh untuk menentukan besarnya persentase ketelitian pemetaan. Evaluasi ketelitian pemetaan meliputi jumlah piksel area contoh yang diklasifikasikan dengan benar atau salah, pemberian nama kelas secara benar, persentase banyaknya piksel dalam masing-masing kelas serta persentase kesalahan total.

\section{KESIMPULAN DAN SARAN}

Dari hasil dan pembahasan yang dilakukan dalam peneltian ini, maka dapat disimpulkan beberapa hal yaitu

1. Pada rentang waktu tahun $2008-2011$ terjadi penambahan luas wilayah pesisir (Akresi) sebesar ,770 $\mathrm{Km}^{2}$ dengan laju penambahan 1,192 $\mathrm{Km}^{2}$ per-tahunnya. Sedangkan pada rentang waktu 2011 - 2014 besarnya akresi hanya 0,087 $\mathrm{Km}^{2}$ dengan laju penambahan sebesar $0,021 \mathrm{Km}^{2}$ atau $21 \mathrm{~m}^{2}$ per-tahunnya. Pengurangan garis pantai (abrasi) pada tahun 2011 - 2014 yakni sebesar $0,704 \mathrm{Km}^{2}$ dengan laju abrasi $0,176 \mathrm{Km}^{2}$ atau $176 \mathrm{~m}^{2}$ pertahunnya.

2. Perhitungan tingkat akurasi interpretasi Perubahan Garis pantai citra Landsat tahun 2008 - tahun 2014 diperoleh akurasi seluruh pemetaan sebesar $90,9 \%$.

Adapun saran yang diberikan adalah sebagai berikut

1. Diperlukan ketelitian dan kesabaran baik pada saat melakukan digitasi ataupun pada saat melakukan identifikasi pada citra.

2. Perlu adanya campur tangan pemerintah daerah setempat dan semua stake holders terkait untuk melakukan upaya peningkatan pengamanan yang tegas terhadap tindakan penataan dan rehabilitas ekosistem mangrove sebagai pilar pengembangan wilayah di Kawasan
Pesisir Kecamatan Talawi Kabupaten Batubara, agar kerusakan lebih lanjut bisa dicegah dan sebisa mungkin bisa mengembalikan berbagai fungsi ekosistem mangrove bagi kesejahteraan masyarakat pesisir.

3. Pemerintah daerah bersama-sama dengan masyarakat dapat melakukan program penghijauan atau penanaman mangrove seluas 100 200 meter dari pinggir pantai terluar untuk menghijaukan kembali daerah pesisir pantai Kecamatan Talawi Kabupaten Batubara.

\section{DAFTAR PUSTAKA}

Dinas Kehutanan Batu Bara. 2010. Data Kehutanan Batubara 2010.Batubara : Dinas Kehutanan.

Harti, Arum Mustika. 2009. Perubahan Garis Pantai Teluk Jakarta Tahun 1970 - 2009.Skripsi, Depok :Fakultas Matematika dan Ilmu Pengetahuan Alam.

Http://id.wikipedia.org/wiki/Penginder aan_jauh diakses tanggal 6 Juli 2015 pukul 12.15

Clark, R.J. 1996. Coastal Zone Management Hand Book. CRC Lewis Publishers. Boca raton, Florida.

Lilisan dan Kiefer. 1990. Penginderaan Jauh dan Interpretasi Citra. Terjemahan Gajah Mada University Press.Yogyakarta.

NurYuwono. 1992. Dasar- Dasar Perencanaan Bangunan Pantai, Laboratorium

Sakka et al. 2011. Studi perubahan garis pantai di delta sungai Jeneberang, Makassar.J. Ilmu dan Teknologi Kelautan Tropis: 3(2):112-126.

Suci S, Rafiqah. 2012. Perubahan Wilayah Pantai dan Penutupan Lahan pada 
Muara Sungai Pappa di Kabupaten Takalar.Skripsi, Makassar :Fakultas Pertaniam Universitas Hasanuddin.

Sugandi, A.1992. Pendekatan Pembangunan dan Penataan Ruang Wilayah Pesisir. Bogor: Makalah Kursus Pelatihan Pengelolaan SumberDaya Wilayah Pesisir Secara Terpadu. PPLH IPB.

Sulistriani, Yunita. 2009. Perubahan Daratan Pantai dan Penutupan Lahan Pasca Tsunami Secara Spasial dan Temporal di Pantai Pangandaran, Kabupaten Ciamis Jawa Barat. Skripsi.Bogor. : Fakultas Perikanan dan Ilmu Kelautan Institut Pertanian Bogor.

Sutanto.1986. Penginderaan Jauh Jilid I. UGM Press. Yogyakarta.

Susilo, S. B. dan J. L. Gaol. 2008. DasarDasar Penginderaan Jauh Kelautan. Departemen Ilmu dan Teknologi Kelautan, Fakultas Perikanan dan Ilmu Kelautan, Institut Pertanian Bogor. Bogor

Taufiqurrahman,dkk. 2012. Analisis Spasial Perubahan garis Pantai di Pesisir Kabupaten Subang Jawa Barat.Jurnal Vol. 4,No. 2, Hlm. 280 289, Desember 2012.

Thieler, et all.2009.The Digital Shoreline Analysis System (DSAS) Version 4.0-An ArcGIS Extension for Calculating Shoreline Change.Virginia :US Geological Survey.

Triatmodjo,Bambang.1999.TeknikPantai. Yogyakarta :Beta

Yulius,dkk. 2013. Perubahan Garis Pantai di Teluk Bungus Kota Padang, Provinsi Sumatera Barat Berdasarkan Analisis Citra Satelit.jurnal Vol.5,No. 2, Hlm. 417 - 427, Desember 2013 